\title{
GEOGRAPHICAL PERSPECTIVES ON HERITAGE CONSERTVATION AND SUSTAINABILTY IN MEWAR REGION
}

\author{
P. R. Vyas ${ }^{1}$, Kiran Meena ${ }^{2}$ and Vishnu Shanker Paliwal ${ }^{2}$ \\ ${ }^{1}$ Former Head and Professor, ${ }^{2}$ Research Scholars \\ Department of Geography, Faculty of Earth Science, \\ M.L. Sukhadia University, Udaipur, (Raj.) India \\ Email: prvyasgeog@gmail.com
}

\begin{abstract}
Paper focused on status of heritage conservation and sustainability sites in the Mewar Region of the Rajasthan. Indeed, historical heritage mainly forts emerged as strongholds in the Mewar region. Such physical structures have been involving several devices in the defence system of a state evolved from very early times but more vigorously between 10th and 16th centuries. Mainly Chief ship centres like Chittaurgarh and Udaipur, cities are continued to survive in the present day landscape as elements of architectural and historical monuments toward touristic interests. Prominent features of physical structures of heritage sites have been considered as key elements like defence system comprising of series of walls, ramparts, battlements, towers, moats, and gates were supplemented by the socio-economic as well as cultural arrangements and structures within and surroundings of the forts. Besides these features provision for community services had also been well executed during that time such as water reservoirs, wells, Palaces, civil lines, human habitations, places of worship like temples, multi-storeyed towers, cenotaphs sacred precincts were given proper space as per requirement of the contemporary society resided within the premises of the forts.
\end{abstract}

Key words: Historical Monuments, Heritage, Archaeological Sites, Architectural

\section{Introduction}

In India, the first instance of conservation was when Emperor Ashok ordered to conserve wildlife in the 3rd century BC. Then in the 14th century AD, Firuz Shah Tughlaq ordered to protect ancient buildings. Later, during the British Rule, the "Bengal Regulation (XIX)" was passed in 1810, and the "Madras Regulation (VII)" was passed in 1817. These regulations vested the government with the power to intervene whenever the public buildings were under these regulations vested the government with the power to intervene whenever the public buildings were under threat of misuse. Then in 1863, Act XX was passed which authorised the government to "prevent injury to and preserve buildings remarkable for their antiquity or for their historical or architectural value". However, many historic structures were destroyed by the government (pre independence) itself in Shahjahanabad. The Archaeological Survey of India (ASI) was established in 1861 to initiate legal provision to protect the historical structures all over India. The "Ancient Monuments Preservation Act (VII)" was passed in 1904 which provided effective preservation and authority over the monuments, and in 1905 for the first time, 20 historic structures in Delhi were ordered to be protected.

At the time of independence, 151 buildings and complexes in Delhi were protected by the central ASI. The State Department of Archaeology was set up in 1978 in Delhi, but 
it lacks the power to acquire or protect buildings, and merely looks after some monuments denotified by ASI. In 1984, Indian National Trust for Art and Cultural Heritage (INTACH) was founded to stimulate awareness for conservation of cultural heritage among the people. Some studied have been conducted like In1975 Feilden, estimated that by the end of the century only10 percent of the architectural heritage will "survive", 1989, he gave a more "optimistic" estimation, saying that hopefully it will be more than 20 percent. to a similar conclusion came Winkler 1973, who included results of many different studies on stone deterioration (time lapse) and concluded that most of the stones surfaces should be strongly deteriorated by the end of the 20thcentury. The Constitution of India has divided the jurisdiction over these monuments, cultural heritage, and archaeological sites.

\section{Study Area}

Study focused on sustainability of selected historical heritage sites like forts and palaces of the Mewar region. An attempt has been made to analyse an architectural importance of the world class heritage sites like Chittaurgarh and Kumbhalgarh forts and two historical palaces like City Palace of the Udaipur city, Hadi Rani Palace of the Slumber. Such historical monuments not only have still their existence within premises but also have their socio -cultural impact too.

Figure 01: Study Area, Mewar Region and Selected Heritage Sites

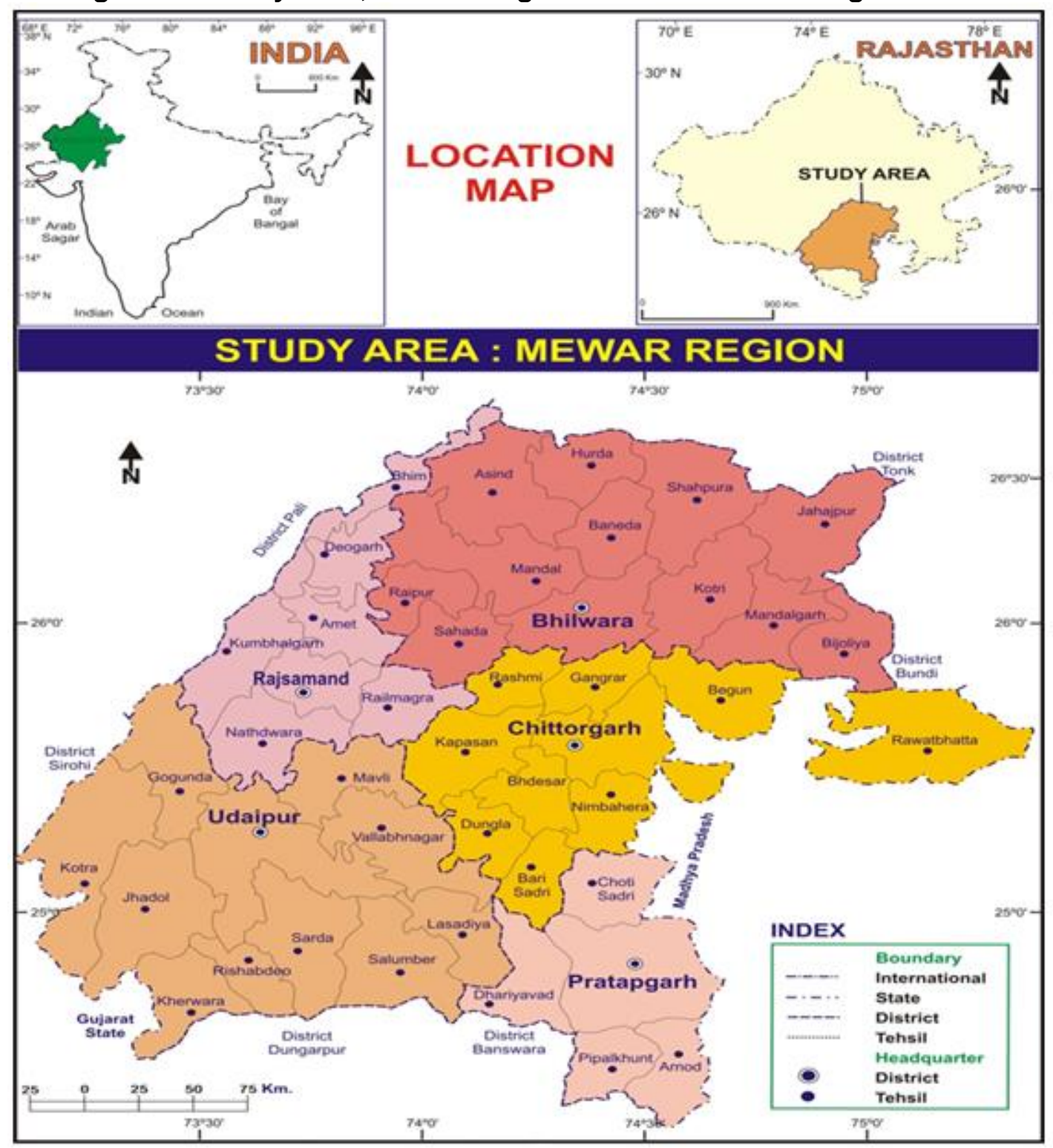




\section{Geographical Location}

The Mewar Region is located in the southern Rajasthan and astronomically situated between $23^{\circ} 50^{\prime}$ to $25^{\circ} 55^{\prime}$ North Latitudes and $73^{\circ} 07^{\prime}$ and $75^{\circ} 51^{\prime}$ East. It includes the present-day districts of Bhilwara, Chittorgarh, Rajsamand, Udaipur and Pratapgarh. It is a compact land mass bordered by the district of Dungarpur and Banswara in the south, the district of Pali and Sirohi in the west and the district of Ajmer and Tonk in the North and Bundi and Kota in the East. In terms of geographical regions, study region is bordered by Malwa and Hadoti regions in the east, Aravali range in the North-West and khari river in the North and Mahi river basin in the south.

\section{Historical Background}

In fact, main threat is to be maintained an originality of the heritage monuments located on the in various places of the region. Which have been developed by the past generation that we observe today and to be sustained for future generations also. Indeed, heritage monuments are the imprint of our cultural heritage that have been provided foe us by the past generations. Thus considering the back ground our historical heritage, it would be very much logical to mention that Professor A. N. Bhattacharya (2000) discussed the historical importance of the heritage sites in his book (Human Geography of the Mewar) and emphasized that the "Fort as a key element of the cultural heritage and elaborated that "Forts not merely served as Garrisons, but have also been places of great architectural beauty, embodied in various types of structures, the massive walls, lofty gateway, palaces, pillars, temples, cenotaphs, pillared , halls, water reservoirs and each of the gateways of Chittaurgarh and of the same number at Kumbhalgarh does not only example of attempt at maximum possible defence capability by virtue of locational orientation and massiveness of each of these gateways, but also as objects of great architectural and artistic splendour." In the study region, where the defence system comprising of series of walls, ramparts, bastions, battlements, towers, moats, and gates were supplemented by the socio-economic as well as cultural arrangements and structures within the fort, such as provision of land for agriculture purposes water reservoirs, and wells, According to Tod, J. (Annals and Antiquities of Rajasthan Vol. I p. 231, 1971, New Delhi) as many as 84 forts were erected through -out Mewar for its defence, of which has many as 83 were constructed by the Maharana Kumbha alone. As per present findings, there were in all 93 forts of which 7 have been shown to be in ruins and these have been located in the different locations of the Mewar region. Of course 93 forts, 82 were found to be in the former Mewar or Udaipur state at present covered by the Bhilwara, Chittaurgarh, Rajsamand and Pratapgarh and Udaipur district, while 5 forts are Located in "Vagad" i. e. Dungarpur and Banswara districts and 6 in adjoining cultural region of "Malwa" located in the state of Madhya Pradesh, parts of which at a time were included in the state of Mewar.

\section{Review of Important work on Heritage Studies}

The literature Review reveals that many authors have written on cultural and historical heritage towards sustainable developments and conservations of monuments. A very few authors have worked on the various location which have their geographical and cultural relevance. The state possesses a rich cultural heritage evident in these famous historical monuments in form of forts temples, museums, lakes etc. Bruce M. (1994) focused on stress-capability framework, the problems and opportunities for sustainable development at the village level in Bali are examined. Balinese culture incorporates a traditional form of local government which emphasizes cooperation, consensus building, and balance. These aspects provide a strong foundation for sustainable development initiatives. At the same time, many decisions are being taken external to the villages, and even to Bali which may leads to problems for development initiate. Robinson Rowan, J., Andrea, R. \& William, W. (1995) explained Sustainable Development and the Development Control Process. This paper explained the far local planning authorities, through their development control powers, are likely to be able to fulfil this role. It concludes that a dramatic change in the system is not required but that some difficulties could arise. These difficulties focus on the 
interrelation between the presumption in favour of development and the precautionary approach, the elasticity of the term 'other material considerations', the 'once and for all' nature of development control and the problem of determining whether development will be sustainable.

Conclaves (2007) has presented an overview of how integrated conservation of urban scale heritage is managed in the urban rehabilitation practice in Portugal and its relation with local urban planning. The central argument is that the safeguard of urban scale heritage is mainly a question of urban management and urban planning, which necessarily implies a framework that results from conciliation among the culture and the land use administrations. Rojas (2007) The conservation and development of the urban heritage: A task for all social actors. There is a growing interested in Latin America for preserving and developing the rich urban heritage of the region. Communities are pressing governments for more action and supporting the allocation of funds to these uses. The article argues that the sustainable conservation of urban heritage sites requires: putting the heritage assets to uses for which a demand exists and the involvement of all social actors in their most efficient capacity and in accordance with their best interests. Smith, H. \& Azcona, E. J. L. (2012) has explained the historical development of built heritage awareness and conservation policies: a comparison of two World Heritage Sites: Edinburgh and Salvador do Bahia. Values regarding built heritage have developed historically in response to both international agendas and local circumstances, and have underpinned the creation of World Heritage Sites and regeneration approaches within these.

Bertacchini, E. \& Segre, G. (2016). discussed "Culture, sustainable development and social quality: A paradigm shift in the economic analysis of cultural production and heritage conservation". The aim of this paper the special issue is to address the changing paradigm that the economic analysis of cultural production and heritage preservation has undergone. New emphasis on the role of creativity in society, the spread of the digital revolution and the reconsideration of culture and heritage as drivers of sustainable development and social quality are radically changing the analytical perspectives and research agenda. Tiwari, R. \& Patel J. (2016) analysed Cultural Heritage and Indian Economy in terms of Cultural heritage, classic and contemporary, contributes to the identity and branding of territory, so relevant in an age of globalization and fierce competition, as also the base for sustainable and endogenous development. Vyas, P. R. \& Paliwal, V. S. (2016) studied on "Urban heritage conservation and management: A geographical analysis of Udaipur city of Rajasthan, in terms of importance of conservation and sustainability of Urban Heritage and historical monuments. In fact, Urban heritage one area that always considered as humane, socio-cultural and economic asset observed by various research scholars in terms of architectural values that have been produced by successive and existing cultures and an accumulation of traditions and experiences, recognized as such in their diversity.

\section{Objectives}

Following objectives have been taken into considered as given under:

- To understand the historical background of the heritage sites of the study region.

- To discuss the importance of architectural values of heritage sites.

- To focus the practices of conservation of heritage sites and monuments.

- To project policy implication for sustainability of heritage sites.

\section{Major Heritage Sites}

Nevertheless, key elements of historical heritage are historical forts of the region which are pride of the Country like Chittaurgarh Fort and Kumbhalgarh Fort etc. also declared as world heritage sites by the UNESCO. In fact, need for secured living like those of food and tool making has been among the fundamental human needs in all ages. Thus such type of fortification has been ranging from thorny hedges of stockades of the primitive times to more sophisticated fortification forms undertaken by early civilized peoples of the Fertile 
Crescent extending from old civilizations. Fortification have been devised in India from the times of the Indus valley urban Civilization to those of the Vedic times. Major forts of the Mewar are Chittaurgarh, and Kumbhalgarh located in the central western part of the region respectively. Major forts like Chittaurgarh and Kumbhalgarh and Palaces(mahal) such as City palace of the Udaipur city and Slumber Rawala (Palace) of the Mewar region have been taken into account of the study on the basis historical importance and their geographical location.

Table 01: Characteristics of the Selected Heritage Sites of the Study Region

\begin{tabular}{|l|l|l|l|l|l|}
\hline$\#$ & $\begin{array}{l}\text { Name of } \\
\text { Heritage Site }\end{array}$ & $\begin{array}{l}\text { Heritage } \\
\text { Importance }\end{array}$ & Present status & $\begin{array}{l}\text { Efforts for } \\
\text { Conservation }\end{array}$ & $\begin{array}{l}\text { Efforts for } \\
\text { Sustainability }\end{array}$ \\
\hline 1 & $\begin{array}{l}\text { Chittaurgarh } \\
\text { Fort } \\
\text { (Chittaurgarh } \\
\text { District) }\end{array}$ & $\begin{array}{l}\text { Historical Heritage } \\
\text { site, as world } \\
\text { heritage site } \\
\text { recognized By } \\
\text { UNESCO }\end{array}$ & $\begin{array}{l}\text { Fort has its } \\
\text { existence and one of } \\
\text { the major attraction } \\
\text { for tourism } \\
\text { Maintenance } \\
\text { by ASI / RTDC, } \\
\text { GOR }\end{array}$ & $\begin{array}{l}\text { Developed } \\
\text { Infrastructure by } \\
\text { the state Govt. } \\
\text { for tourism }\end{array}$ \\
\hline 2 & $\begin{array}{l}\text { Kumbhalgarh } \\
\text { (Rajsamand } \\
\text { District) }\end{array}$ & $\begin{array}{l}\text { Historical Heritage } \\
\text { Fort as world site } \\
\text { heritage recognized } \\
\text { By UNESCO }\end{array}$ & $\begin{array}{l}\text { Fort has its } \\
\text { existence and also } \\
\text { one of the major } \\
\text { attraction for tourism }\end{array}$ & $\begin{array}{l}\text { Monitoring and } \\
\text { Maintenance } \\
\text { by ASI/ RTDC, } \\
\text { GOR }\end{array}$ & $\begin{array}{l}\text { Developed } \\
\text { Infrastructure by } \\
\text { the state Govt. } \\
\text { for tourism }\end{array}$ \\
\hline 3 & $\begin{array}{l}\text { City Palace } \\
\text { Udaipur } \\
\text { (Udaipur City) }\end{array}$ & $\begin{array}{l}\text { Touristic Importance } \\
\text { site }\end{array}$ & $\begin{array}{l}\text { Monitoring by } \\
\text { Mewar Trust / } \\
\text { RTDC GOR/ ASI }\end{array}$ & $\begin{array}{l}\text { Infrastructure } \\
\text { developed by the } \\
\text { Mewar Trust/ } \\
\text { State govt. }\end{array}$ \\
\hline 4 & $\begin{array}{l}\text { Hada Rani } \\
\text { palace } \\
\text { (Slumber Town } \\
\text { Udaipur District) }\end{array}$ & $\begin{array}{l}\text { Historical Heritage } \\
\text { site }\end{array}$ & Regional tourism & $\begin{array}{l}\text { Monitoring at } \\
\text { Private level }\end{array}$ & $\begin{array}{l}\text { Some of the } \\
\text { State Govt } \\
\text { offices are } \\
\text { located in the fort }\end{array}$ \\
\hline
\end{tabular}

\section{Chittorgarh Fort}

The famous Chittor Garh (Fort) is situated on the plateau of Aravali Hills located in Chittaurgarh city, which is one of the largest forts in India and Asia. Hindu rulers fought fiercely to maintain their independence. Chittaurgarh fort is originally called Chitrakuta, and the Chittorgarh is said to have been built by Chitranga, a king of the Maurya (mori) clan. It was constructed by the Mauryans in the 7th century AD. There is also a belief that it was constructed by Bhima of the Pancha Pandavas. This fort was the citadel of many great Indian warriors such as Gora, Badal, Rana Kumbha, Maharana Pratap, Jaimal, Patta, etc.

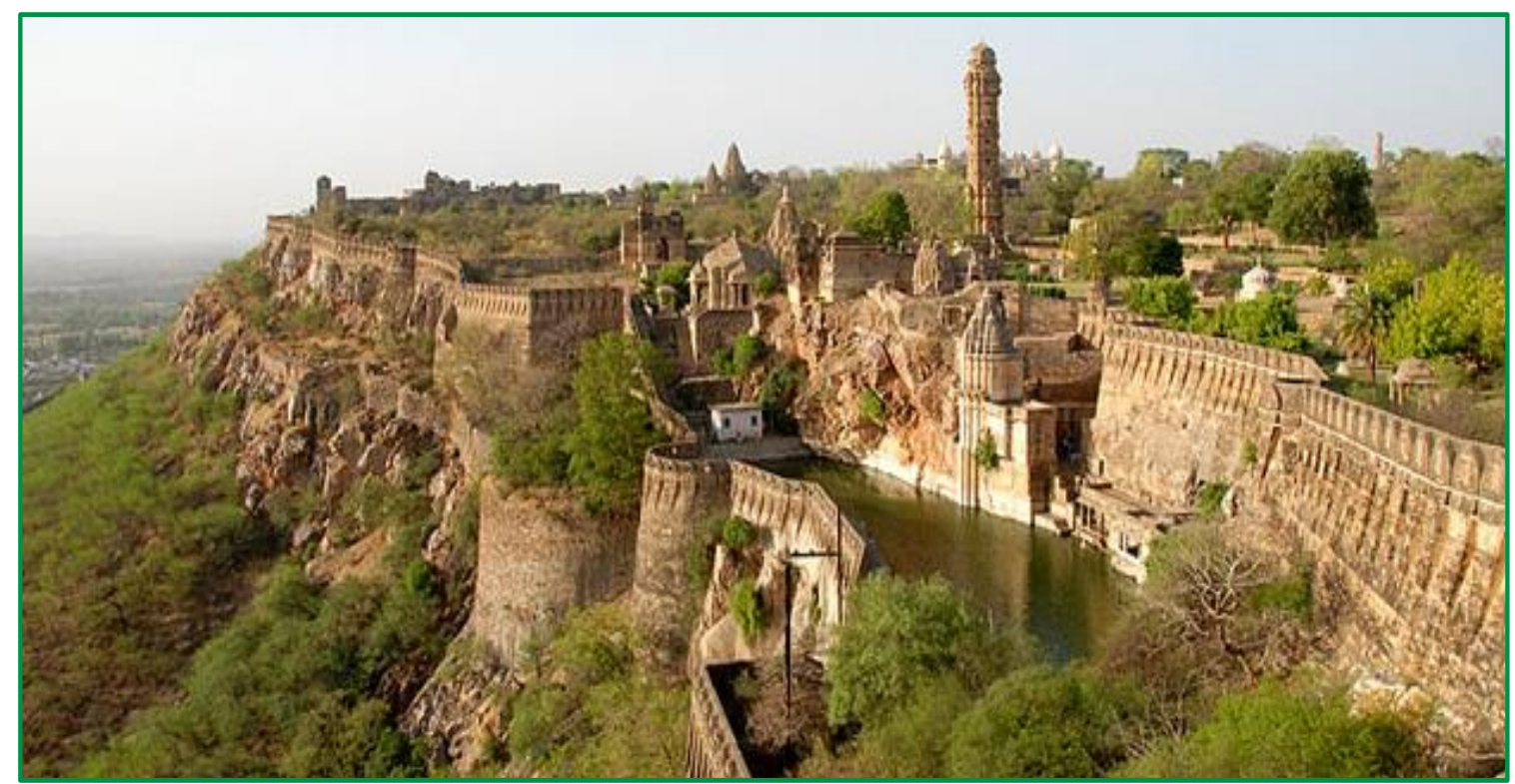

Plate 01: Chittaurgarh Fort: It was the Capital of Mewar Region in Medieval Age (Between $7^{\text {th }}-16^{\text {th }}$ Century AD) 


\section{Kumbhalgarh (literally "Kumbhal fort")}

The Kumbhalgarh fort have been built by King Samprati of the Maura Age for strategic point of view and due to its geographical locational importance during the 6th century. Kumbhalgarh in its current shape was built by Rana Kumbha who was the Rana (King) of the Mewar belonged to the Sisodia Rajput clan. The fort was built under architect of the era, Mr. "Madan" as assigned by Maharana Kumbha. It was the Maha Rana Kumbha's kingdom of Mewar was extended and stretched from Ranthambore to Gwalior and included large tracts of erstwhile Madhya Pradesh as well as Rajasthan. There were out of the 84 forts in his dominion and32 of them built by the Rana Kumbha and out of which Kumbhalgarh is the largest and most elaborate fort. Geographically the fort of Kumbhalgarh is situated on the top of the hills of the southern Aravali Hills near Mt. Jarga Ji (second highest peak after Mt. Guru Shikhar) and also separated Mewar (Eastern plain region of Rajasthan) and Marwar (Western Desert Region of Rajasthan) from each other.

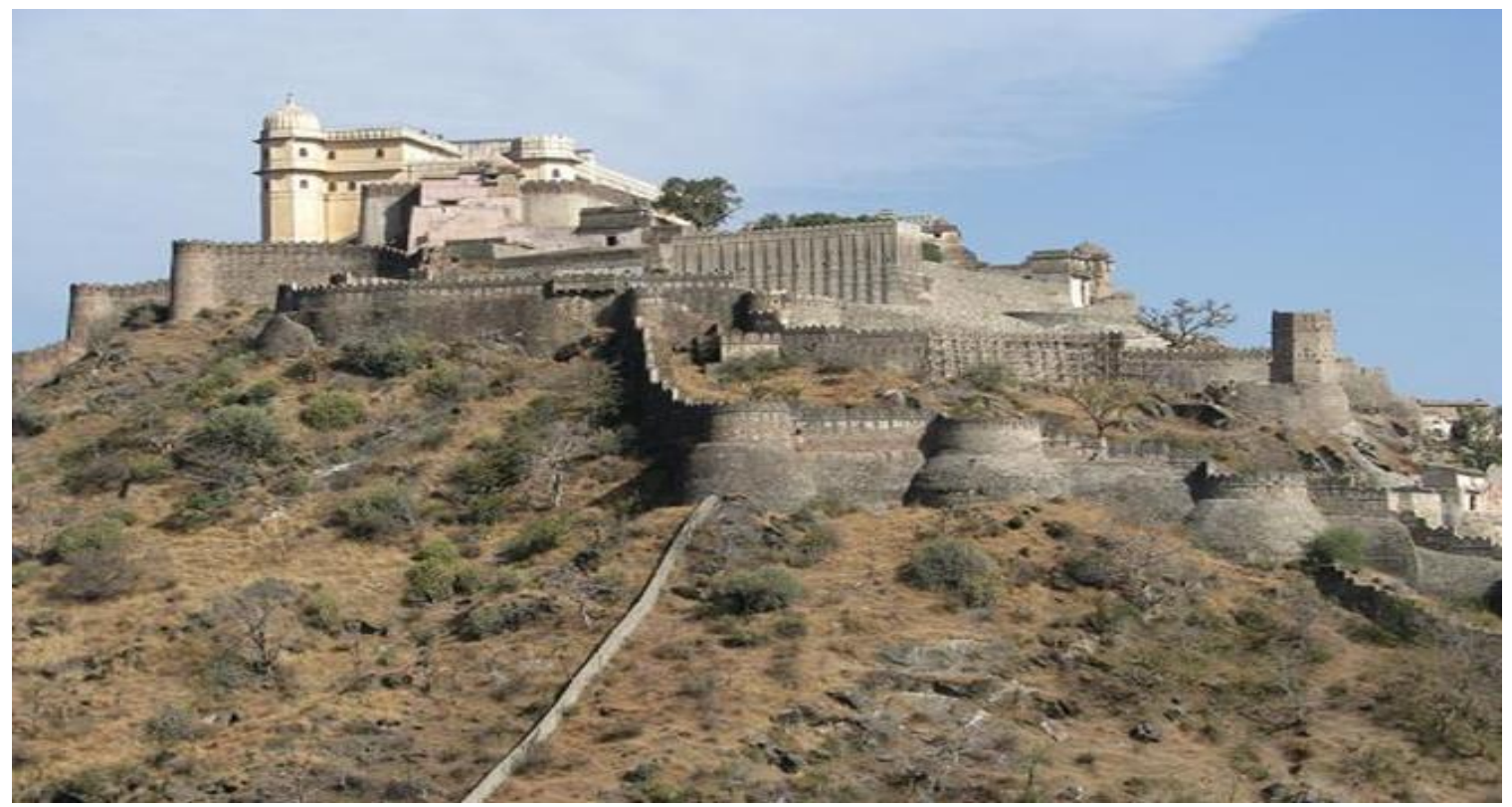

Plate 02: Overview of Kumbhalgarh Fort

Kumbhalgarh is known as the strongest fort among major forts of the country. There are different important structures that had been built during the initial stage of the construction of the fort of Kumbhalgarh including Palace (Badal Mahal) Great Boundary wall of Fort (Chardiwari), temples (Jain and Shiva), residential houses of public resided in the premises of the fort roads made by boulders, water tanks, ware houses for protection of grains and other structures constructed for the sources of Drinking water like wells, stepping wells, (kund and Baories) etc. There are Magnificent 52 cenotaphs (Chatries) of Jain Temple constructed inside of fort of Kumbhalgarh. Where Parsva Natha temple built during $1513 \mathrm{AD}$, other Jain temples located on the eastern side and Bawan (52) Jain temples and Golera Jain temple the major Jain temples constructed in the fort.

\section{City Palace of Udaipur}

The City Palace was built concurrently with the establishment of the Udaipur city by Maharana Udai Singh II and his successor Maharanas over a period of the next 400 years. The Maharanas lived and administered their kingdom from this palace, thereby making the palace complex an important. 


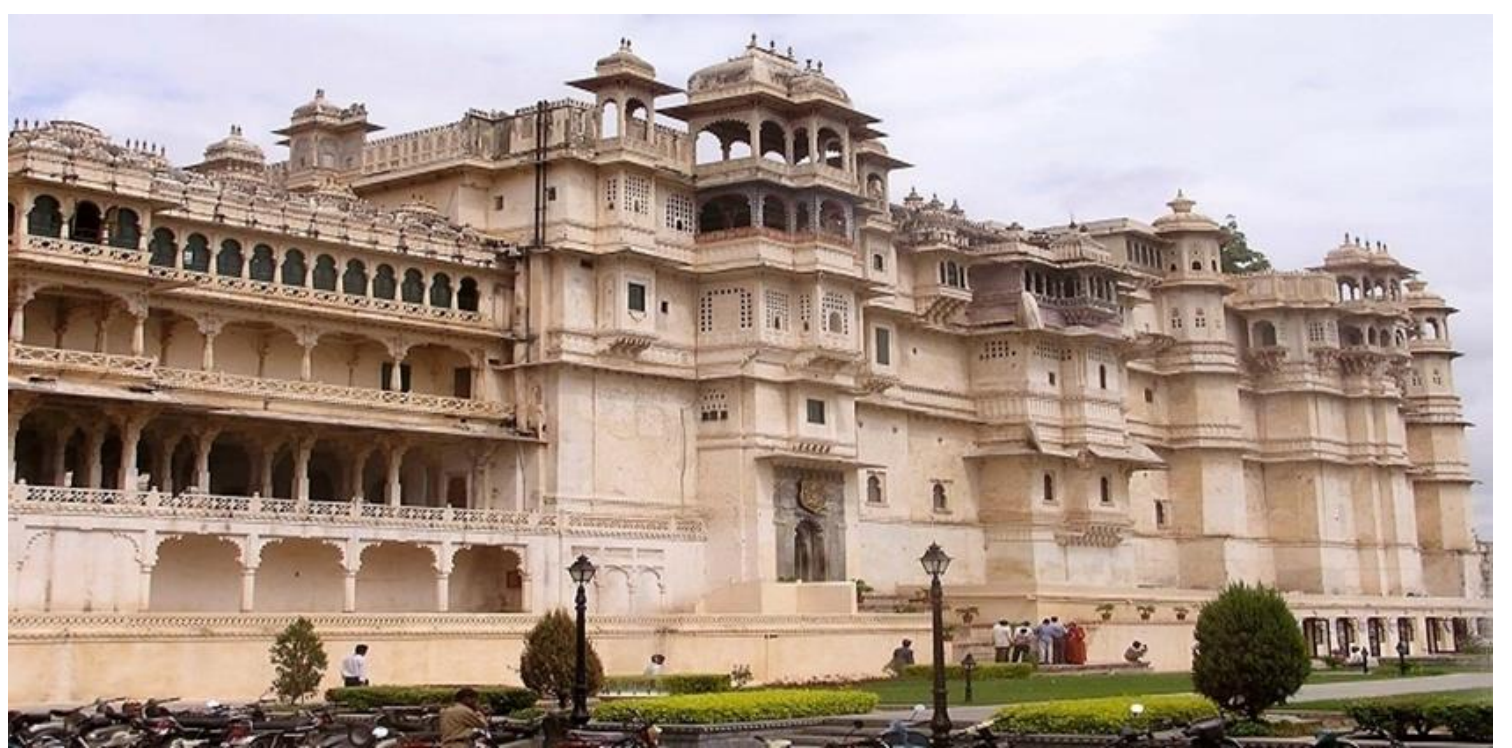

Plate 03: Historic land mark having Architectural Importance known as the "City Palace of the Udaipur City"

\section{Slumber Palace (Raoalas)}

Hadi Rani was the Hada Rani was the queen of the Maharana Raj Singh Rajasthan in India. She was a daughter of a Hada Chauhan Rajput married to a Chundawat chieftain of Slumber in Mewar who sacrificed herself to motivate her husband to go to war. When (1653-1680) Mewar called his commander to join the battle against Aurangzeb, the commander, having married only a few days earlier hesitated about doing so. Perceptions of Rajput honour caused him to join the battle despite his reservations. He asked his wife, Hadi Rani, for some memento to take with him to the battlefield. Thinking that she was an obstacle to his doing his duty for Mewar, she cut off her head and put it on a plate. He fought bravely, making the Aurangzeb forces flee, and after his victory, he got to his knees and cut his neck, having lost the desire to live. There are various water tanks constructed along with the strong wall of the fort. Such Baories, stepping wells and Tanks were treated as sources of Drinking water locally known as, Kund and Baories. The premises of the fort have some building structures presently which are being used for Government schools, govt. offices etc.

\section{Planning for Heritage Conservation}

Conservation of heritage places initiated by the ASI (Archaeological Survey of India) for some selected areas of the study region. As per survey reported by historians who were working on architectural monuments and heritage places like forts, temples, stepped wells, (Kund and Baories) have observed that many historic monuments seemingly deteriorated at a much higher rate than it should have been expected only by natural ageing. Some observations have been taken into consideration for planning of heritage conservation as given under:

- This effect could be visualized impressively in comparative studies of documents that showed the preservation state of some monuments at the beginning of the20th century and approx.

- It was well understood, that scientific research is necessary to understand the processes of deterioration of materials and also to develop methods for rehabilitation and conservation of the endangered heritage.

- It is not possible to give here an overview of all activities and achievements that have been done at different level like for the protection of historic and monuments and the specific research for a better understanding of their decay processes.

- Many different disciplines from science, humanities, architecture, engineering, geographers, and others can come together and try to find solutions for problems and they can share their experiences. 
- Such cooperation needed several years of intensive exchange and discussions and it seems that it started to work now for sustainability of heritage monuments.

\section{Sustainability of the Heritage Sites}

Sustainability means keep alive or to prove true that provide base for the protection of the Heritage sites. Basic idea behind sustainability of the heritage sites is to develop a process in which heritage structure can be sustained for future generation. Evidently that can be maintained through monitoring system and also having coordination between the different agencies which are working in that direction under the guide line given by the Archaeological Survey of India (ASI) and other agencies are State Department of Tourism (RTDC) and local administration too. Evidently the whole variety of historic building structures and other monuments consisting out of a variety of stone material, metals, brick structures and many other different cultural materials do behave in their environment differently that varies place to place and even region to region and country to country too. Efforts can be done towards sustainability:

1. Sustainable development always focuses on inter -generational fairness in the exploitation of development opportunities.

2. Thus Heritage structures always symbolized culture of the past generation, can be traced through carving on stones, figures depicted on the walls of the palaces, forts, temples, towers, stepping wells, cenotaphs, boundary walls of the forts etc. should be intact in all respect.

3. Measures initiated toward sustainability for the heritage monuments is based on pure empirical knowledge are certainly a good prevention.

4. Although scientific research gives clear results, however often not much success when applied in practice but initiation and efforts in terms of sustainability is always appreciated to maintain existence of each and every monument in the region at some extent.

5. The main achievement of the years lying now behind us was the creation of an interdisciplinary cooperation of all persons and bodies that integrated both scientific and practical experiences.

\section{Conclusion}

It is concluded that the conservation of heritage structures like forts and historical monuments are an interdisciplinary effort, wherein traditional knowledge on building materials, techniques and specifications are brought to the realm of current practitioners of conservation engineering, with the intent of merging them with modern tools and practices. While formal systemsthat was recognised for conservation of heritage monuments as an interdisciplinary engineering effort, with structural safety as a critical determinant should be applied toward sustainability. In fact, quality and quantity of the manpower is a serious problem that should be solved through employment generations and opportunities should be given to the local people. Those who are experienced persons or have been working in the relevant field and addressing the task of understanding and protecting heritage structures and applied their skill for protection from natural hazards, ageing and weathering effects.

\section{References}

1. Bertacchini, E. \& Segre, G. (2016) Introduction: Culture, sustainable development and social quality: A paradigm shift in the economic analysis of cultural production and heritage conservation. Sustainable Development and Social Quality, Volume 7(2), Pages 69-70.

2. Bhattacharya, A. N. (2000) Human Geography of Mewar, Himanshu Publications, Udaipur, Delhi

3. Bruce, M. (1994) Sustainable Development at the Village Level in Bali, Indonesia. Human Ecology, Vol. 22 (2), Page-189-211 
4. Goncalves, A. (2007). Which urban plan for an urban heritage? An overview of recent Portuguese practice on integrated conservation. www.ct.ceci.br.org.

5. Harvey, R. "UNESCO'S Memory of the World Program". Library Trends 56, no. 1 (2007): 259-274

6. Jackson R. (2011) Heritage buildings and sustainability forum, Architecture BulletinMarch-April

7. Mumford L. (1965), Techniques and Civilization, McGraw Hills, pp.430-30.

8. Robinson, Rowan, J., Andrea, R. \& William, W. (1995). Sustainable Development and the Development Control Process. Liverpool University Press, The Town Planning Review, Vol. 66 (3) pp. 269-286.

9. Rojas, E. (2007) The conservation and development of the urban heritage: A task for all Social actors. CECL, 3(1), pp. 41-47. www.ct.ceci.br.org.

10. Sen Priyadarshani (2017). Urban Planning of Bengaluru Metropolitan Region. The Deccan Geographers, Vol. 55, No. 1 \& 2, June and Dec. published by the Deccan Geographical Society, India, ISSN 0011-7269.

11. Singh, R.L. (1961) Meaning, objectives and scope of settlement Geography, NGJI, Varanasi, Vol.8-11, pp.12-20.

12. Smith, A. (2003) "Valuing Preservation". Library Trends 56, no. 1 (2007): 4- 25.

13. Smith, D.M. (1977) Pattern in human geography, Penguin Book Std., England:180-188.

14. Smith, H. \& Azcona, E.J.L. (2012). The historical development of built heritage awareness and conservation policies: a comparison of two world heritage site: Edinburgh and Salvador do Bahia. Springer Science, www.springer.com/static/pdf/435

15. Technical Guide: Guidelines for Conducting Historical Archaeological Surveys.

16. UNESCO, Convention for safe guarding the Intangible Heritage. Paris: UNESCO,

17. Vyas, P.R. \& Paliwal, V.S. (2016) "Urban heritage conservation and management: A geographical analysis of Udaipur city of Rajasthan, India". Journal of Urban and Regional Studies, UGC centre for Advanced Studies, Department of Geography, Osmania University, Hyderabad, India. Vol. 2 (2), ISSN No. 2350-1162. 